\title{
TNFRSF6B wt Allele
}

National Cancer Institute

\section{Source}

National Cancer Institute. TNFRSF6B wt Allele. NCI Thesaurus. Code C51384.

Human TNFRSF6B wild-type allele is located in the vicinity of 20q13.3 and is approximately $41 \mathrm{~kb}$ in length. This allele, which encodes tumor necrosis factor receptor superfamily member 6B protein, is involved in the inhibition of apoptosis. 